\title{
PENGARUH EKSTRAK PROPOLIS TERHADAP EKSPRESI PROTEIN Bcl2, p21, DAN INDUKSI APOPTOSIS PADA SEL HELA
}

\author{
EFFECT OF PROPOLIS EXTRACT TOWARD BCI2 \& P21 EXPRESSION, AND \\ APOPTOSIS INDUCTION ON HELA CELL LINE
}

\author{
Tri Hadi Susanto, Suradi Maryono, Bambang Purwanto \\ Sub Bagian Hemato Onkologi Medik, Bagian Ilmu Penyakit Dalam \\ FK UNS / RSUD Dr. Moewardi Surakarta \\ Korespondensi: dr. Tri Hadi Susanto, Sp. PD. Email: susanto_dr@yahoo.co.id
}

\begin{abstract}
AbstraK
Kanker serviks merupakan penyebab kematian ketiga akibat kanker pada wanita di dunia. Di Indonesia, kanker serviks merupakan penyebab kematian utama perempuan dalam tiga dasa warsa terakhir. Berbagai strategi terapi pengobatan kanker serviks dengan menggunakan terapi bedah, radioterapi, dan kemoterapi maupun kombinasi ketiganya relatif belum optimal. Setiap abnormalitas pada jalur apoptosis dapat sebagai target terapi kanker. Pendekatan yang menarik untuk dikembangkan adalah penggunaan kombinasi kemoterapi atau ko-kemoterapi. Propolis yang menunjukkan aktivitas proapoptosis pada berbagai jenis sel kanker, meliputi : kanker laring, kanker paru, kanker pankreas, kanker tiroid, kanker kolorektal, kanker payudara, kanker prostat dan glioma. Propolis merupakan salah satu produk natural yang potensial untuk dikembangkan sebagai agen ko-kemoterapi. Tujuan penelitian ini untuk mengetahui pengaruh pemberian propolis yang berasal dari Kerjo, Karanganyar, Indonesia terhadap induksi proses apoptosis dan aktivitas antiproliferasi, terutama terkait dengan penekanan ekspresi protein Bcl2 dan peningkatan aktivasi p21 pada kultur sel HeLa (cell line kanker servik). Penelitian ini merupakan penelitian eksperimental laboratorik dengan menggunakan post test with control group design. Penelitian dilakukan pada kultur sel HeLa (sel kanker servik) dengan pemberian propolis. Pengamatan ekspresi p21 dan ekspresi protein Bcl2 dilakukan dengan metode imunositokimia, sedangkan pengamatan induksi apoptosis dilakukan dengan flowcytometry. Hasil penelitian menunjukkan ekspresi rata-rata Bcl2 pada kelima kelompok yaitu kontrol 84,60 $\pm 1,34 \mu \mathrm{g} / \mathrm{ml}$, EEP $1 / 2 \mathrm{IC}_{50} 62,33 \pm 4,58$, EEP IC $\mathrm{I}_{50} 33,98 \pm 2,11 \mu \mathrm{g} / \mathrm{ml}$, EEP 2 IC $_{50}$ $22,16 \pm 3,41 \mu \mathrm{g} / \mathrm{ml}$, Cisplatin 13,09 $\pm 4,38 \mu \mathrm{g} / \mathrm{ml}$. Terdapat perbedaan bermakna ekspresi Bcl2 antara kelompok uji dibandingkan kelompok kontrol ( $\mathrm{p}<0,001)$. Rata-rata ekspresi p21 pada kelima kelompok yaitu pada grup kontrol 1,70 $\pm 0,67 \mu \mathrm{g} / \mathrm{ml}$, EEP 1/2 $\mathrm{IC}_{50} 65,92 \pm 0,40$, EEP IC $\mathrm{I}_{50} 82,76 \pm 3,03 \mu \mathrm{g} / \mathrm{ml}$, EEP $2 \mathrm{IC}_{50} 86,86 \pm 3,33 \mu \mathrm{g} /$ $\mathrm{ml}$, Cisplatin 93,19 $\pm 3,02 \mu \mathrm{g} / \mathrm{ml}$. Terdapat perbedaan bermakna ekspresi p21 antara kelompok uji dibandingkan kelompok kontrol $(\mathrm{p}<0,001)$. Penelitian ini menyimpulkan bahwa pemberian ekstrak etanol propolis mempunyai pengaruh terhadap penekanan ekspresi Bcl2, peningkatan ekspresi p21, dan induksi apoptosis pada kultur sel kanker servik (HeLa cell line).
\end{abstract}

Kata Kunci: EEP, p21, protein Bc12, HeLa cell line

Cervical cancer was the third leading cause of cancer in women in the world. In Indonesia, cervical cancer was the leading cause of female death in the last three decades. Various strategies of cervical cancer treatment therapy using surgical therapy, radiotherapy, and chemotherapy or a combination of the three are relatively not optimal. Any abnormality in the path of apoptosis can be a target of cancer therapy. An interesting approach to develop is the use of a combination of chemotherapy or co-chemotherapy. Propolis that shows proapoptosis activity in various types of cancer cells, including: laryngeal cancer, lung cancer, pancreatic cancer, thyroid cancer, colorectal cancer, breast cancer, prostate cancer and glioma. Propolis is one of the potential natural products to be developed as a co-chemotherapy agent. The purpose of this study was to investigate the effect of propolis administration from Kerjo, Karanganyar, Indonesia to induction of apoptotic process and antiproliferative activity, mainly related to suppression of Bcl2 protein expression and increased activation of p21 on cell culture of cervical cancer. This study was laboratory experimental research using post test with control group design. This study was conducted on cell culture HeLa (cervical cancer cells) with propolis administration. The observed expressions of 221 and Bcl2 protein expression were performed by immunocytochemical method, while the observation of apoptotic induction 
was done by flowcytometry. The results showed that the average expression of Bcl2 in the five groups was 84.60 $\pm 1.34 \mu \mathrm{g} / \mathrm{ml}$ in the control group, $62.33 \pm 4.58$ in the EEP $1 / 2 \mathrm{IC}_{50}, 33.98 \pm 2.11 \mu \mathrm{g} / \mathrm{ml}$ in the EEP $I C_{50}$, $22.16 \pm 3.41 \mu \mathrm{g} / \mathrm{ml}$ in the EEP $2 \mathrm{IC}_{50}$, and $13.09 \pm 4.38$ $\mu \mathrm{g} / \mathrm{ml}$ in the cisplatin group. There was a significant difference in Bcl2 expression between the test groups versus the control group ( $p<0.001)$. The average expression of $p 21$ in the five groups was $1.70 \pm 0.67$ $\mu \mathrm{g} / \mathrm{ml}$ in the control group, $65.92 \pm 0.40$ in the EEP $1 / 2 \mathrm{IC}_{50}, 82.76 \pm 3.03 \mu \mathrm{g} / \mathrm{ml}$ in the $E E P I C_{50}, 86.86 \pm$ $3.33 \mu \mathrm{g} / \mathrm{ml}$ in the EEP $2 \mathrm{IC}_{50}, 93.19 \pm 3.02 \mu \mathrm{g} / \mathrm{ml}$ in the cisplatin group. There were significant differences in p21 expression between the treatment groups versus the control group $(p<0.001)$. This study concluded that ethanol propolis administration has an effect on Bcl2 expression suppression, increased expression of p21, and induction of apoptosis in cervical cancer cell culture (HeLa cell line).

Keywords: EEP, p21, Bcl2 protein, HeLa cell line

\section{PENDAHULUAN}

Kanker merupakan penyakit yang melibatkan faktor genetik dalam proses patogenesisnya, proses pembelahan sel menjadi tidak terkontrol karena gen yang mengatur pertumbuhan sel mengalami inaktivasi (Marleen et al., 2009). Kanker serviks merupakan penyebab kematian ketiga akibat kanker pada wanita dengan 529.000 kasus baru di dunia pada tahun 2008 (IARC,2010). Prevalensi kanker serviks di Provinsi Jawa Tengah dari tahun ke tahun semakin meningkat, dari $0,02 \%$ pada tahun 2006, menjadi 0,03\% pada tahun 2007, dan pada tahun 2008 masih tetap 0,03\%. Pada tahun 2007, prevalensi tertinggi adalah di Kota Semarang sebesar 0,22\% (Depkes, 2009).

Berbagai strategi terapi pengobatan kanker serviks telah dilakukan diantaranya dengan menggunakan terapi bedah, radioterapi, dan kemoterapi maupun kombinasi ketiganya, namun hasilnya relatif belum optimal. Terapi pembedahan bersifat terbatas karena hanya dapat diterapkan pada penderita kanker serviks stadium awal dan penderita usia muda yang telah kehilangan fertilitasnya, sedangkan radioterapi dan kemoterapi sering menimbulkan efek samping yang berat (Fujimoto, 2009).

Kemoterapi didasarkan pada kerusakan DNA sehingga menyebabkan kematian sel baik melalui apoptosis maupun nekrosis (Hakem dan
Harrington, 2005). Kemoterapi belum memberikan hasil yang optimal dan sering menimbulkan efek samping yang serius karena pada umumnya tidak bekerja secara spesifik pada sel kanker tetapi juga pada sel normal (Goldie, 2001).

Oleh karena itu, terdapat suatu kebutuhan untuk mengembangkan terapi alternatif pengelolaan kanker, selain modalitas terapi utama (Li et al., 2014). Sejumlah penelitian telah menunjukkan bahwa peningkatan konsumsi diet nabati yang teratur dapat mengurangi risiko kanker. Oleh karena itu, banyak studi yang saat ini difokuskan pada temuan senyawa bioaktif baru dari sumber alami dan sejumlah besar produk alami yang telah dievaluasi mempunyai potensi kemopreventif ( Lin et al, 2012).

Salah satu produk natural yang potensial untuk dikembangkan sebagai agen ko-kemoterapi adalah propolis. Propolis telah lama dikenal dan digunakan sebagai obat tradisional yang memiliki berbagai efek menguntungkan meliputi anti bakteri, anti fungi, anti virus, imunostimulator, dan anti kanker ( Bancova, 2007). Popolis terrdiri dari campuran resin, serbuk sari dan lilin tanaman yang dikumpulkan lebah dari berbagai jenis tanaman dan digunakan untuk proteksi sarang lebah dari mikroba (Ananda et al., 2013 ; Watanabe et al., 2011). Secara umum, kandungan propolis adalah asam lemak, asam alifatik, asam aromatik, flavonoid, alkohol, terpene, gula, dan ester. Komposisi senyawa kimiawi dan aktivitas biologi propolis bervariasi tergantung lokasi geografi, asal tanaman, musim dan spesies lebah (Paulino et al., 2009).

Hal yang relatif menjanjikan dari propolis, yaitu terkait dengan aktivitas antikanker yang dimilikinya. Sejak tahun 2003, berbagai penelitian menfokuskan pada pengaruh propolis terhadap sinyal tranduksi intraseluler yang menunjukkan bahwa beberapa target penting pada sel kanker dapat dimodulasi melalui pemberian propolis. Peran propolis di dalam terapi keganasan terkait dengan kemampuannya dalam menginduksi apoptosis dan aktivitas antiproliferasi. Pada berbagai penelitian in vitro, propolis menunjukkan aktivitas proapoptosis pada berbagai jenis sel kanker, meliputi : kanker laring, kanker paru, kanker pankreas, kanker thyroid, kanker kolorektal, kanker payudara, kanker prostat dan glioma (Kubina et al., 2015). 
Penelitian yang dilakukan oleh Motomura et al. (2008) mengindikasikan bahwa ekstrak metanol dari propolis meningkatkan apoptosis pada sel U937 akibat aktivasi caspase-3 dan penurunan protein Bcl-2. Overaktivitas caspase-6 yang diinduksi oleh Ekstrak Etanol Propolis (EEP) lebih kuat dibandingkan aktivitas caspase-8 dan caspase-9 yang terinduksi pada sel MCF7 pada penilitian Vatansever et al (2007), yang membuktikan adanya keterlibatan jalur caspase intrinsik dari apoptosis dan aktivitas antitumor dari propolis.

Hasil pengamatan tersebut juga sejalan dengan hasil penelitian dari Eom et al (2010) di mana propolis menginduksi apoptosis melalui pelepasan sitokrom c dari mitokondria ke dalam sitosol dan melalui aktivasi caspase-3 pada sel leukemia manusia HL-60 dengan konsentrasi yang ditentukan $(3-50 \mu \mathrm{g} / \mathrm{ml}$ untuk sitokrom c dan 10-50 $\mu \mathrm{g} / \mathrm{ml}$ untuk caspase-3). Aktivitas antikanker propolis ini dipengaruhi oleh geografis dan tumbuhan sebagai asal pengumpulan resin oleh lebah untuk membentuk propolis. Dua faktor tersebut mempengaruhi komposisi dari propolis (Syamsudin et al., 2009).

Berdasarkan fakta-fakta yang diuraikan di atas, mendorong peneliti untuk mengetahui pengaruh pemberian propolis yang berasal dari Kerjo, Karanganyar, Indonesia terhadap induksi proses apoptosis dan aktivitas antiproliferasi, terutama terkait dengan penekanan ekspresi protein $\mathrm{Bcl} 2$ dan peningkatan aktivasi p21 pada kultur sel HeLa (cell line kanker servik). Penelitian ini sebagai upaya penemuan dan pengembangan strategi baru dalam melawan kanker, khususnya kanker servik dengan memanfaatkan kekayaan sumber daya hayati local.

\section{METODE PENELITIAN}

Penelitian ini merupakan penelitian eksperimental laboratorik dengan menggunakan post test with control group design. Penelitian dilakukan pada kultur sel HeLa (sel kanker servik) dengan pemberian ekstrak etanol propolis dan cisplatin sebagai kontrol positif.

Pengamatan ekspresi $\mathrm{Bcl} 2$ dan ekspresi p21 dilakukan dengan metode imunositokimia, sedangkan pengamatan induksi apoptosis dilakukan dengan flowcytometry menggunakan pewarnaan annexin $V$ dan propidium iodida (PI).

\section{HASIL DAN PEMBAHASAN}

\section{Uji sitotoksisitas dengan MTTassay untuk menetapkan nilai $I_{50}$ ekstrak etanol propolis dan Cisplatin.}

Uji sitotoksistas dilakukan setelah kultur sel siap dipanen, sel HeLa yang ditumbuhkan pada media komplit, selanjutnya diberikan perlakuan dengan senyawa propolis. Sel HeLa yang hidup memiliki morfologi seperti epitel gepeng lonjong dan menempel pada dasar sumuran, sedangkan sel HeLa yang mati berbentuk bulat kecil, tersebar dan tidak menempel pada dasar sumuran. Morfologi sel HeLa ditunjukkan pada Gambar 1.

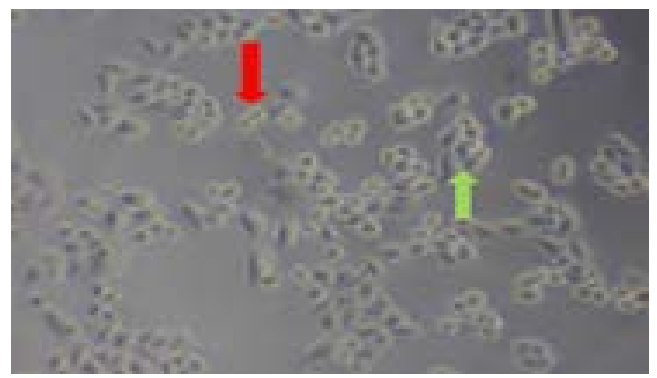

Gambar 1. Morfologi Sel HeLa, sel hidup ditunjukkan panah warna hijau dan sel mati ditunjukkan panah warna merah. Sel diamati dengan mikroskop inverted dengan perbesaran $100 \mathrm{kali}$. 
Tabel 1. Nilai rata-rata persentase viabilitas sel $\mathrm{HeLa}$ dan nilai $\mathrm{IC}_{50}$ bahan uji dengan metode $M T T$ assay.

\begin{tabular}{cccc}
\hline Bahan Uji & Konsentrasi $(\mu \mathrm{g} / \mathrm{mL})$ & $\begin{array}{c}\text { Rata-rata viabilitas sel HeLa }(\% \\
\pm \mathrm{SD})\end{array}$ & $\mathrm{IC}_{50} \pm \mathrm{SD}(\mu \mathrm{g} / \mathrm{mL})$ \\
\hline \multirow{3}{*}{ Ekstrak Etanol Propolis (EEP) } & 12,5 & $89,98 \pm 1,97$ & \\
& 25 & $69,66 \pm 4,41$ & $70,42 \pm 1,07$ \\
& 50 & $49,22 \pm 1,75$ & $19,44 \pm 1,42$ \\
Cisplatin & 100 & $7,15 \pm 1,26$ & $45,72 \pm 48,82$ \\
& 200 & $100,63 \pm 18,01$ & \\
\end{tabular}

Untuk mengetahui aktivitas sitotoksisitas dari senyawa propolis yang diujikan pada sel $\mathrm{HeLa}$ dilakukan dengan menggunakan metode MTT assay. Inkubasi dilakukan selama 24 jam setelah pemberian propolis, kemudian diberi penambahan reagen yellow MTT. Data yang didapatkan dari uji sitotoksisitas dengan MTT assay berupa absorbansi dari tiap sumuran yang merupakan hasil pembacaan dengan ELISA reader pada panjang gelombang $595 \mathrm{~nm}$.

Data tersebut kemudian diolah lebih lanjut dengan cara membandingkan nilai absorbansi antara sel yang diberi perlakuan dan kontrol (sel tanpa perlakuan) setelah masing-masing dikurangi dengan kontrol media (blank). Data tersebut digunakan untuk menetapkan nilai $\mathrm{IC}_{50}$ bahan uji dengan menggunakan analisis regresi linear antara dosis bahan uji dan persentase viabilitas sel HeLa. Nilai rata-rata persentase viabilitas sel $\mathrm{HeLa}$ dan $\mathrm{IC}_{50}$ dari bahan uji ditunjukkan pada Tabel 1.

Secara umum bahan uji mampu menghambat proliferasi sel HeLa. Hal ini terlihat dari semakin ditingkatkan konsentrasi bahan uji semakin sedikit persentase viabilitas sel HeLa. Aktivitas sitotoksisitas bahan uji ini dinyatakan dengan nilai $\mathrm{IC}_{50}$ yang diperoleh melalui analisis regresi linear antara logaritma konsentrasi bahan uji dengan persentase viabilitas sel HeLa. Dari analisis regresi linear diperoleh $\mathrm{IC}_{50}$ EEP sebesar 70,42 ug/uL. Nilai $\mathrm{IC}_{50}$ EEP ini digunakan sebagai dasar penentuan konsentrasi EEP yang digunakan pada penelitian selanjutnya, yaitu sebesar 35, 70, dan $140 \mathrm{ug} / \mathrm{uL}$ $\left(1 / 2 \mathrm{IC}_{50}, \mathrm{IC} 50\right.$, dan $\left.2 \mathrm{IC}_{50}\right)$. Nilai $\mathrm{IC}_{50}$ cisplatin akan digunakan sebagai pembanding pada uji apoptosis, yaitu sebesar 45,72 ug/uL.

\section{Pengamatan ekspresi Bcl2}

Protein Bcl-2 menghambat kerja caspase dengan mencegah pelepasan sitokrom $\mathrm{c}$ dari mitokondria dan/atau melalui ikatannya dengan faktor aktivasi apoptosis (APAF-1) (Park, 2006 ). Oleh karena itu, untuk mengetahui peningkatan apoptosis sel $\mathrm{HeLa}$ setelah pemberian ekstrak etanol propolis selama 24 jam terkait penekanan ekspresi Bcl2, maka dilakukan pengamatan penekanan ekspresi Bcl2 pada sel HeLa dengan pengecatan imunositokimia.

Pengecatan imunositokimia untuk $\mathrm{Bcl} 2$ dilakukan pada 5 kelompok perlakuan (kontrol, 1/2 IC50, IC50, 2 IC50, Cis IC50), dan masingmasing kelompok perlakuan tersebut dibuat triplicate. Data yang diperoleh berupa persentase sel yang mengekspresikan $\mathrm{BCl} 2$ (tampak sebagai warna coklat pada inti sel maupun sitoplasma) dari keseluruhan sel pada 5 lapangan pandang dan penilaiannya dilakukan pada 3 slide dari tiap-tiap kelompok perlakuan. Hasil pengecatan imunositokimia untuk ekspresi $\mathrm{Bcl} 2$ pada sel HeLa tampak pada Gambar 2 dan grafik hubungan antara konsentrasi ekstrak etanol propolis dengan rata-rata ekspresi Bcl2 pada sel HeLa dapat dilihat pada gambar 3. 


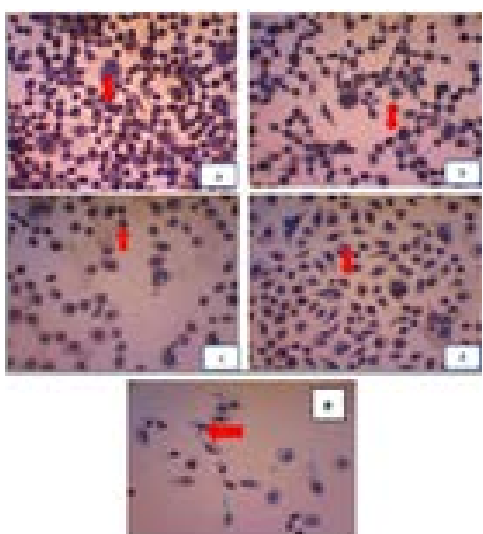

Gambar 2.Hasil pengecatan imunositokimia perbesaran 400 kali untuk ekspresi Bcl2 pada sel $\mathrm{HeLa}$ setelah perlakuan dan inkubasi selama 24 jam pada kelompok dengan EEP konsentrasi $1 / 2 \operatorname{IC50}(\mathrm{a}), \mathrm{IC}_{50}$ (b), $2 \mathrm{IC}_{50}$ (c), kelompok dengan Cisplatin (d) dan kelompok kontrol (e). Sel yang mengekspresikan Bcl2 ditunjukkan dengan panah warna merah.

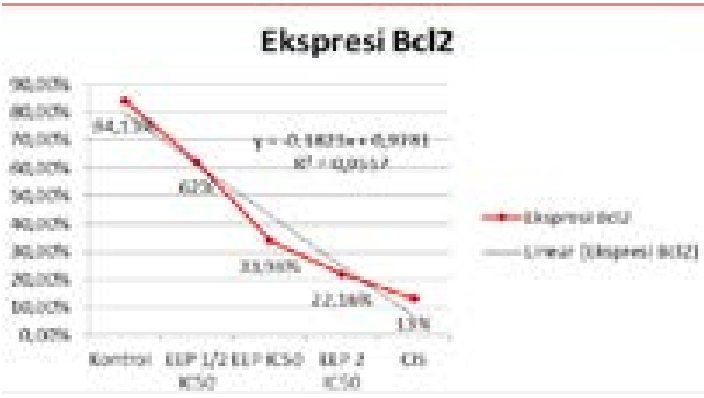

Gambar 3.Hubungan antara konsentrasi bahan uji dengan rata-rata persentase ekspresi Bcl2 pada sel $\mathrm{HeLa}$ setelah inkubasi 24 jam.

Dari grafik di atas, terlihat bahwa pemberian ekstrak etanol propolis selama 24 jam menekan ekspresi Bcl2. Penekanan ekspresi Bcl2 sebanding dengan peningkatan konsentrasi ekstrak etanol propolis yang diberikan. Hasil uji statistik menunjukkan adanya perbedaan ekspresi $\mathrm{Bcl} 2$ yang bermakna diantara kelima kelompok perlakuan $(\mathrm{p}<0,05)$. Hasil uji Mann whitney menunjukkan bahwa perbedaan ekspresi Bc12 yang bermakna terletak diantara semua kelompok perlakuan yang mendapatkan ekstrak etanol propolis dan cisplatin dibandingkan dengan kelompok kontrol $(\mathrm{p}<0,05)$.

\section{Uji induksi apoptosis EEP pada sel $\mathrm{HeLa}$} dengan flowcytometry

Setelah inkubasi selama 24 jam, dilakukan uji apoptosis dengan metode flowcytometry dan tiap-tiap kelompok perlakuan dibuat duplicate. Data hasil flowcytometry yang diperoleh berupa persentase sel HeLa yang hidup, mengalami apoptosis, maupun nekrosis pada kelima kelompok perlakuan (Gambar 4). Rata-rata persentase sel HeLa yang mengalami apoptosis pada kelima kelompok perlakuan ditampilkan pada tabel 2.


Gambar 5.Hasil flowcytometry sel HeLa setelah perlakuan dan inkubasi selama 24 jam pada kelompok kontrol (a), kelompok dengan Cisplatin $\mathrm{IC}_{50}(\mathrm{~b}), \mathrm{IC}_{50}(\mathrm{c})$ dan $2 \mathrm{IC}_{50}(\mathrm{~d})$ serta kelompok dengan pemberian Cispltin konsentrasi

$$
\mathrm{IC}_{50}(\mathrm{e})
$$

Keterangan untuk tiap-tiap kuadran:

$\begin{array}{llll}\text { - Kiri Bawah (Anexin negatif, } & \text { PI } \\ \text { negatif) }: \text { Sel hidup } & & \\ \text { Kanan Bawah (Anexin } & \text { positif, } & \text { PI } \\ \text { negatif) : Sel apotosis } & & \\ \text { Kanan Atas (Anexin positif, } & \text { PI } \\ \text { positif) }: \text { Sel nekrosis } & & \end{array}$

Tabel 2.Rata-rata persentase sel HeLa yang mengalami apoptosis setelah inkubasi selama 24 jam dengan bahan uji (EEP dan 5-FU) maupun pada kelompok kontrol.

$$
\begin{array}{cc}
\text { Perlakuan } \quad \text { Konsentrasi }(\mathrm{mM}) \quad \begin{array}{c}
\text { Rata-rata Apoptosis Sel HeLa } \\
(\%) \pm \mathrm{SD}
\end{array} &
\end{array}
$$

\begin{tabular}{ccc}
\hline Kontrol Sel & 0 & $1,6 \pm 0,14$ \\
Propolis & $35(1 / 2$ IC50) & $3,11 \pm 0,13$ \\
& $70($ IC50) & $21,47 \pm 0,64$ \\
& $140(2$ IC50) & $35,58 \pm 0,96$ \\
Cisplatin & $45,72($ IC50) & $42,58 \pm 1.03$ \\
\hline
\end{tabular}

Data pada tabel 2 menunjukkan bahwa rata-rata persentase apoptosis pada sel $\mathrm{HeLa}$ meningkat sebanding dengan peningkatan konsentrasi propolis yang diberikan. Hal ini 
menunjukkan bahwa ekstrak etanol propolis mampu menginduksi apoptosis pada sel HeLa sebanding dengan peningkatan konsentrasi yang diberikan.

Hasil uji Anova menunjukkan adanya perbedaan yang bermakna yang bermakna diantara kelima kelompok perlakuan( $\mathrm{p}<0,05)$. Hasil multiple comparisons test menunjukkan bahwa perbedaan rata-rata persentase apoptosis sel HeLa yang bermakna secara statistik terletak diantara kelompok perlakuan yang mendapatkan propolis ataupun cisplatin dibandingkan dengan kelompok kontrol tanpa perlakuan $(\mathrm{p}<0,05)$.

\section{Pengamatan ekspresi protein $p 21$}

p21 adalah suatu tumor suppresor protein dengan berat $21 \mathrm{KDa}$ memiliki fungsi utama dalam regulasi terhadap progresi siklus sel. Propolis dapat menghambat siklus sel dengan menekan ekspresi cyclin A, cyclin B, dan Cdk, meningkatkan kadar protein p21 dan p27 dan menghambat efek hTERT pada sel tumor (Diana, 2012). Berdasarkan hal ini, untuk mengetahui apakah penghambatan proliferasi sel HeLa oleh propolis terkait dengan aktivasi $\mathrm{p} 21$, maka dilakukan pengamatan aktivasi p21 pada sel HeLa setelah pemberian ekstrak etanol propolis dan inkubasi selama 24 jam.

Pengamatan ini dilakukan dengan pengecatan imunositokimia terhadap p21 pada 5 kelompok perlakuan (kontrol, 1/2 IC50, IC50, dan 2 IC50,Cis). Hasil pengecatan imunositokimia untuk p21 pada sel HeLa tampak pada Gambar 6.


Gambar 6. Hasil pengecatan imunositokimia perbesaran 400 kali untuk ekspresi p21 pada sel $\mathrm{HeLa}$ setelah perlakuan dan inkubasi selama 24 jam pada kelompok dengan EEP konsentrasi $1 / 2 \operatorname{IC50}$ (a), $\operatorname{IC}_{50}(\mathrm{~b}), 2 \mathrm{IC}_{50}$ (c), Cisplatin (d) dan kontrol (e). Sel yang mengekspresikan p21 ditunjukkan dengan panah warna merah.

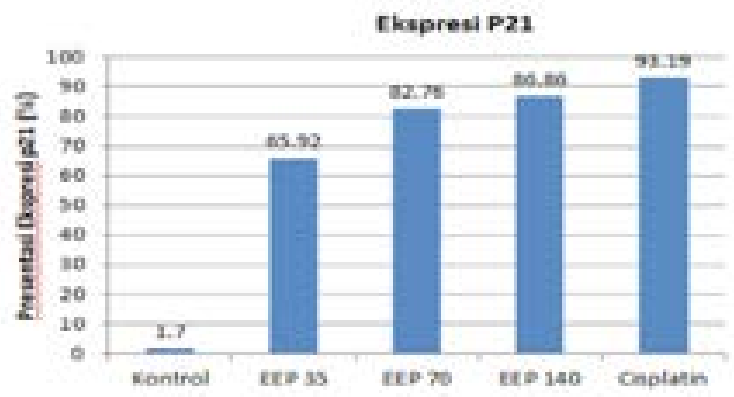

Gambar 7. Hubungan antara konsentrasi bahan uji dengan rata-rata persentase ekspresi protein $\mathrm{p} 21$ pada sel $\mathrm{HeLa}$ setelah inkubasi 24 jam.

Dari grafik di atas, terlihat bahwa pemberian propolis selama 24 jam meningkatkan ekspresi p21. Peningkatan ekspresi p21 sebanding dengan peningkatan konsentrasi ekstrak etanol propolis 
yang diberikan. Hasil uji statistik menunjukkan adanya perbedaan ekspresi p21 yang bermakna diantara kelima kelompok perlakuan $(\mathrm{p}<0,05)$.

Penelitianinidiawalidengan uji sitotoksisitas senyawa ekstrak etanol propolis (EEP) pada sel HeLa menggunakan metode MTT assay. Uji sitotoksisitas ini dilakukan untuk menetapkan nilai $\mathrm{IC}_{50}$ senyawa EEP yang selanjutnya akan digunakan sebagai dasar penetapan konsentrasi EEP untuk pengamatan ekspresi protein Bcl-2, p21 maupun uji induksi apoptosis pada sel HeLa. Selain itu, uji sitotoksisitas ini juga digunakan untuk menetapkan $\mathrm{IC}_{50}$ Cisplatin pada sel $\mathrm{HeLa}$ sebagai kontrol positif pada uji induksi apoptosis.

Pada uji sitotoksisitas ini secara umum didapatkan persentase hambatan proliferasi sel $\mathrm{HeLa}$ semakin meningkat sebanding dengan peningkatan konsentrasi ekstrak propolis yang diberikan. Hal ini menunjukkan bahwa pemberian ekstrak propolis konsentrasi 12,5- 200 mM selama 24 jam mampu menghambat proliferasi sel HeLa.

Selanjutnya aktivitas sitotoksisitas ekstrak propolis pada sel $\mathrm{HeLa}$ setelah inkubasi 24 jam dinyatakan dengan nilai $\mathrm{IC}_{50}$, yang diperoleh melalui analisis regresi linear antara dosis bahan uji dan persentase viabilitas sel HeLa. Dari analisis regresi linier tersebut diperoleh IC50 ekstrak propolis pada sel HeLa sebesar 70,42 \pm $1,07 \mu / \mathrm{ml}$, menunjukkan aktifitas sitotoksik yang cukup tinggi jika dibandingkan dengan penelitian syamsudin (2011) dimana nilai $\mathrm{IC}_{50}$ propolis sukabumi terhadap sel HeLa sebesar 147,34 \pm 8,9 $\mu / \mathrm{ml}$. Makin kecil nilai $\mathrm{IC}_{50}$ makin aktif propolis sebagai agen antiproliferasi sel kanker.

Induksi apoptosis merupakan salah satu mekanisme yang diajukan sebagai efek terapetik propolis. Penelitian yang dilakukan oleh Motomura et al (2008) mengindikasikan bahwa ekstrak metanol dari propolis $(300 \mu \mathrm{g} / \mathrm{ml}$ dan 500 $\mu \mathrm{g} / \mathrm{ml})$ meningkatkan apoptosis pada sel U937 akibat aktivasi caspase- 3 dan penurunan protein Bcl-2.

Berdasarkan hal ini, dilakukan pengamatan penekanan ekspresi Bcl2 pada sel HeLa untuk menilai apakah kemampuan propolis dalam menghambat proliferasi sel $\mathrm{HeLa}$ pada penelitian ini terkait dengan penekanan ekspresi $\mathrm{Bcl} 2$. Hasil penelitian ini menunjukkan bahwa propolis mampu meningkatkan apoptosis sel $\mathrm{HeLa}$ dan juga mengakibatkan penekanan ekspresi $\mathrm{Bcl} 2$ yang sebanding dengan peningkatan konsentrasi yang diberikan.

Hal ini sejalan dengan penelitian Penelitian yang dilakukan oleh Motomura et al. yang mengindikasikan bahwa ekstrak metanol dari propolis $(300 \mu \mathrm{g} / \mathrm{ml}$ dan $500 \mu \mathrm{g} / \mathrm{ml})$ meningkatkan apoptosis pada sel U937 akibat aktivasi caspase-3 dan penurunan protein Bcl-2. Overaktivitas caspase- 6 yang diinduksi oleh EEP lebih kuat dibandingkan aktivitas caspase- 8 dan caspase-9 yang terinduksi pada sel MCF-7, yang membuktikan adanya keterlibatan jalur caspase intrinsik dari apoptosis dan aktivitas antitumor dari propolis.

Propolis dan senyawanya menginduksi inhibisi proliferasi sel melalui supresi kompleks cyclin dan kinase protein dependen cyclin, dan meningkatkan kadar inhibitor protein seperti p21 dan p27 pada sel tumor (Sawicka, 2012). Berdasarkan hal ini, dilakukan pengamatan aktivasi p21 untuk menilai apakah aktivasi p21 turut berperan dalam mekanisme penghambatan proliferasi sel HeLa oleh propolis.

Pada penelitian ini terlihat bahwa pemberian ekstrak etanol propolis selama 24 jam meningkatkan aktivasi p21 yang sebanding dengan peningkatan konsentrasi ekstrak etanol propolis yang diberikan. Penelitian ini menunjukkan bahwa propolis mampu menghambat proliferasi sel HeLa dan hal ini kemungkinan terkait dengan kemampuan propolis dalam mengaktivasi p21.

Hal ini sejalan dengan hasil penelitian oleh Motomura et al. (2008) dimana Ekstrak metanol dari propolis dengan konsentrasi $100-1.000 \mu \mathrm{g} / \mathrm{ml}$ secara signifikan mampu menghambat pertumbuhan sel U937 dalam dosis yang telah ditentukan. Analisis flow cytometry mengindikasikan bahwa peningkatan $32,8 \%$ (untuk dosis propolis $300 \mu \mathrm{g} / \mathrm{ml}$ ) dan $37,7 \%$ (untuk dosis propolis $500 \mu \mathrm{g} / \mathrm{ml}$ ) pada jumlah sel U937 dalam fase $\mathrm{G} 2 / \mathrm{M}$, terjadi sebagai akibat dari penurunan ekspresi cyclin A, cyclin B, dan CDK2 dan peningkatan kadar protein p21 dan p27.

\section{SIMPULAN}

Terdapat pengaruh pemberian ekstrak propolis terhadap penekanan ekspresi $\mathrm{Bcl} 2$, peningkatan ekspresi protein p21 serta induksi apoptosis pada kultur sel HeLa. 


\section{DAFTAR PUSTAKA}

Ananda, S.K., Tragoolpua, K., Chantawannakul, P., Tragoolpua, Y. 2013. Antioxidant and anticancer cell proliferation of propolis extracts from two extraction methods. Asian Pac J Cancer Prev. 14(11): 6991-6995

Bankova V. 2007. Propolis of Stingless Bee: A Promising Source of Biologically Active Compounds. Pharmacog Rev. 1: 88-92.

Departemen Kesehatan RI (Depkes RI). 2009. Profil Kesehatan Indonesia 2008. Departemen Kesehatan Republik Indonesia. Jakarta

Diana S, Halina C, Maria H, Jacek N.2012. The anticancer activity of propolis. Folia hisyochemica et cytobiologica. Vol 50, No 1,pp 25-37

Eom, H.S., Lee, S.J., Yoon, B.S., Yoo, B.S. 2010. Propolis inhibit the proliferation of human leukemia HL-60 cells by inducing apoptosis through the mitochondrial pathway. Nat Prod Res. 24:375386.

Fujimoto, J. 2009. Novel strategy of anti-angiogenic therapy for uterine cervical carcinomas. Anticancer Res. 29: 2665-2669.

Goldie, J.H., 2001. Drug resisten in cancer: A Perspective. Cancer and Metastasis Rev. 20:63-68

Hakem, R and Harrington, L. Cell death in Tannock, I.F., Hill, R.P., Bristow, R.G., Harrington, L. 2005. The Basic Science of Oncology. $4^{\text {th }}$ Ed. McGraw-Hill. New York.

IARC, 2010. Cervical Cancer Incidence and mortality worldwide in 2008, Dalamh htttp ://www. globocan.iarc.fr

Kubina, R., Dzik, A.K., Dziedzic, A., Bielec, B., Wojtczka, R.D., Buldok, R.J., Wysznynska, M., et al. 2015. The ethanol extract of polish propolis exhibits anti-proliferative and/or pro-apoptotic effect on HCT 116 colon cancer and Me45 malignant melanoma cell in vitro conditions. $A d v$ Clin Exp Med. 24(2): 203-212

Li ZJ, Yao C, Liu SF, Chen L, Xi YM, Zhang W, Zhang GS. 2014. Cytotoxic effect of icaritin and its mechanisms in inducing apoptosis in human burkitt lymphoma cell line. Biomed Research International.

Lin CC, Yu CS, Yang JS, Lu CC, Chiang JH, Lin JP, Kuo CL, Chung JG. 2012. Chrysin, a natural and biologically active flavonoid, influences a murine leukemia model in vivo through enhancing populations of T-and B-cells, and promoting macrophage phagocytosis and NK cell cytotoxicity. In Vivo; 26(4): 665-670

Marleen, F S., Syahruddin, E., Hudoyo, A \& Endarjo, S. 2009. Ekspresi Protein Bcl-2 pada Sediaan Blok Parafin Jaringan Kanker Paru. Jurnal Respirologi Indonesia 29 (4), p 1-14.

Motomura, M., Kwon, K.M., Suh, S.J. 2008. Propolis induces cell cycle arrest and apoptosis in human leukemic U937 cells through Bcl-2/Bax regulation. Environ Toxicol Pharmacol. 26:61-67

Park, Y.P., Choi, S.C.,Cho, M.Y., Song, E.Y., Kim, J.W., Paik, S.G., Kim, Y.K., Kim, J.W., Lee, H.G. 2006. Modulation of Telomerase Activity and Human Telomerase Reverse Transcriptase Expression by Caspase and Bcl-2 Family Proteins in Cisplatin Induced Cell Death. Korean J Lab Med. 26:287-293.

Paulino, N., Abreu, S.R.L., Machodo, G., Silveira, E. 2009. Scientific evidences to pharmacological anticancer action of Baccharis dracunculifolia Brazilian propolis. Rev Pesq Inov Farm. 1(1): $15-26$

Sawicka D, Halina C, Maria H, Jacek N.2012. The anticancer activity of propolis. Folia hisyochemica et cytobiologica. Vol 50, No 1,pp 25-37

Syamsudin, Wiryowidagdo, S., Simanjuntak, P., Heffen, W.L. 2009. Chemical composition of propolis from different region in java and their cytotoxic activity. AJBB. 5(4): 180-183. 
Vatansever, H.S., Sorkun, K. Gurhan, S.I.D., Ozdal-Kurt, F., Turkoz, E., Gencay, O., Salih, B. 2010. Propolis from Turkey induces apoptosis through activating caspases in human breast carsinoma cell lines. Acta Histochem. 112: 546-556

Watanabe, M.A.E., Amarante, M.K., Conti, B.J., Sforcin, J.M. 2011. Cytotoxic constituents of propolis inducing anticancer effect: a review. JPP. 63: 1378-1386 